\title{
Peran Neurolinguistik dalam Pengajaran Bahasa
}

\author{
Tri Budianingsih ${ }^{1}$ \\ ${ }^{1}$ Program Studi Sastra China, Fakultas Sastra, Universitas Al Azhar Indonesia, Komplek Masjid \\ Agung Al Azhar Indonesia, Jalan Sisingamangaraja, Kebayoran Baru, DKI Jakarta, 12110 \\ Penulis untuk Korespondensi / E-mail: tri.budianingsih@uai.ac.id
}

Abstrak-Pertama kali peneliti mengetahui peran neurolinguistik dalam pengajaran bahasa sempat mengalami kebingungan dalam memahami peran tersebut, karena penamaan yang terdengar asing bagi peneliti yang belum pernah didengar sebelumnya, tapi setelah peneliti memahami dan mengetahuinya peneliti mulai tertarik dalam penerapannya di dalam kelas dalam proses belajar mengajar. Metode ini sangat menerapkan pemahaman bahasa dalam otak kanan dan otak kiri manusia, memahami bahasa sasaran atau bahasa asing dengan menggunakan otak kiri atau otak kanan, hal ini dapat diketahui dalam makalah ini. Dari uraian tersebut dapat didefinisikan bahwa Neuro Linguistic Programming merupakan sebuah model yang memprogram interaksi antara pikiran dan bahasa (verbal dan nonverbal) sehingga dapat menghasilkan pikiran dan perilaku yang diharapkan.

Kata Kunci: Neurolinguistict, Language Teaching, Right Brain and Left Brain

Abstract - The first time researchers know the role of neurolinguistics in language teaching was confused in understanding the role, because the naming that sounds unfamiliar to researchers who have never heard before, but after researchers understand and find out researchers began to be interested in the application in the classroom in the learning process. This method greatly applies the understanding of language in the right brain and the human left brain, understand the target language or foreign language using the left brain or right brain, this can be known in this paper. From the description can be defined that Neuro Linguistic Programming is a model that program the interaction between the mind and language (verbal and nonverbal) so as to generate thoughts and behaviors that are expected.

Keywords: Neurolinguistik, Pengajaran Bahasa, Otak Kanan dan Otak Kiri

\section{PENDAHULUAN}

B anyak yang tidak tahu tentang hubungannya peran neurolinguistik dalam pengajaran bahasa. Sebenarnya jika kita mengetahui secara baik peran tersebut pengajar bahasa sedikit lebih mudah dalam pengajarannya untuk membuat siswa mengerti dalam mempelajari bahasa sasaran. Penguasaan bahasa manusia berbeda dengan hewan, sebenarnya hal ini dilandasi oleh dua aspek, yaitu aspek biologis dan aspek neurologis. Walaupun peneliti tidak membahas pada aspek biologis, tapi peneliti hanya menerangkan secara garis besar dari aspek biologis yang dapat diketahui bahwa pertumbuhan bahasa manusia mengikuti jadwal perkembangan genetiknya sehingga suatu unsur bahasa tidak dapat dipaksakan. Sementara itu, aspek neurologis, yaitu kaitan otak dengan bahasa. Chaer mengemukakan bahwa dalam sistem saraf manusia, otak merupakan pusat saraf, pengendali pikiran, dan mekanisme organ tubuh manusia, termasuk mekanisme pemrosesan bahasa. Oleh sebab itu, perkembangan bahasa 
manusia terkait dengan perkembangan otak. Berdasarkan uraian di atas, makalah ini membahas peran neorologis dalam pengajaran bahasa.

\section{TEORI dan METODOLOGI LANDASAN NEUROLOGIS BAHASA}

Faktor yang juga penting dalam penguasaan bahasa adalah faktor neurologis, yakni kaitan antara otak manusia dengan bahasa. Landasan neurologis bahasa inilah yang mampu menjawab bahwa manusia memiliki kemampuan berbahasa, tetapi hewan tidak.

\section{STRUKTUR DAN ORGANISASI OTAK MANUSIA}

Pertumbuhan manusia menjadi penyelidikan para ahli sejak lama, khususnya tentang penyelidikan oleh para ahli palaeneurologi. Penyelidikan ini sudah berlangsung sekitar 3 juta tahun. Hasil penyelidikan ini setidaknya tampak pada ukuran otak manusia yang membesar dari 400 miligram menjadi 1400 miligram. Meskipun ukuran bukan satu-satunya indikator untuk mengukur perubahan fungsi, paling tidak ukuran itu memungkinkan akan adanya fungsi yang bertambah.

Halloway mengemukakan perkembangan otak ini dapat dibagi menjadi empat tahap, yaitu:

1. Tahap perkembangan ukuran

2. Adanya perubahan reorganisasi pada otak

3. Munculnya system fiber yang berbeda-beda daerah-daerah tertentu melalui corpus collosum.

4. Munculnya dua hemisfer yang asimitris.

Sistem saraf merupakan pusat keputusan dan komunikasi tubuh. Sistem saraf terdiri dari dua bagian utama: (a) tulang punggung yang terdiri dari sederetan tulang punggung yang bersambung-sambungan (spinal cord) dan (b) otak. Otak terdiri dari dua bagian: (i) batang otak (brain stem) dan (ii) korteks serebral (cerebral cortex). Otak merupakan pusat dari keseluruhan tubuh. Selain paling penting, otak juga merupakan organ yang paling rumit.

Otak manusia berukuran sekitar 1-1.5kg dengan rata-rata 1330gram. Ukuran tersebut kurang lebih $2 \%$ saja dari ukutan tubuh manusia. Ukuran otak yang sebesar itu membutuhkan $15 \%$ dari seluruh peredaran darah dari jantung dan 20\% dari sumber daya metabolik manusia.

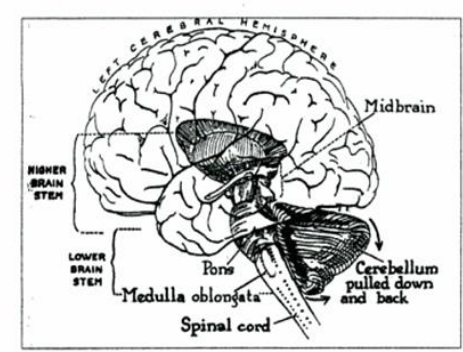

Gambar 1. Struktur Otak Manusia

Seperti terlihat pada gambar di atas, otak dibagi menjadi empat bagian, yaitu:

a. Cerebrum (Otak Besar)

b. Cerebellum (Otak Kecil)

c. Brainstem (Batang Otak)

d. Limbic System (Sistem Limbik)

\section{Cerebrum (Otak Besar)}

Cerebrum adalah bagian terbesar dari otak manusia yang juga disebut dengan nama Cerebral Cortex, Forebrain atau Otak Depan. Cerebrum merupakan bagian otak yang membedakan manusia dengan binatang. Cerebrum membuat manusia memiliki kemampuan berpikir, analisis, logika, bahasa, kesadaran, perencanaan, memori dan kemampuan visual. Kecerdasan intelektual atau IQ juga ditentukan oleh kualitas bagian ini.

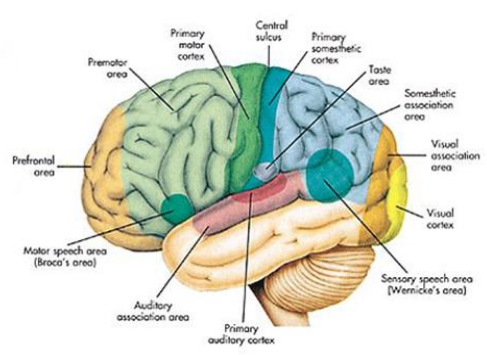

Gambar 2. Struktur dan Organisasi Otak Manusia Cerebrum terbagi menjadi 4 (empat) bagian yang disebut Lobus. Bagian lobus yang menonjol disebut gyrus dan bagian lekukan yang menyerupai parit disebut sulcus. Keempat Lobus tersebut masing-masing adalah: Lobus Frontal, Lobus Parietal, Lobus Occipital, dan Lobus Temporal.

Lobus Frontal merupakan bagian lobus yang ada dipaling depan dari Otak Besar. Lobus ini 
berhubungan dengan kemampuan membuat alasan, kemampuan gerak, kognisi, perencanaan, penyelesaian masalah, memberi penilaian, kreativitas, kontrol perasaan, kontrol perilaku seksual, dan kemampuan bahasa secara umum.

Lobus Parietal berada di tengah, berhubungan dengan proses sensor perasaan seperti tekanan, sentuhan, dan rasa sakit.

Lobus Temporal berada di bagian bawah berhubungan dengan kemampuan pendengaran, pemaknaan informasi, dan bahasa dalam bentuk suara.

Lobus Occipital ada di bagian paling belakang, berhubungan dengan rangsangan visual yang memungkinkan manusia mampu melakukan interpretasi terhadap objek yang ditangkap oleh retina mata.

Apabila diuraikan lebih detail, setiap lobus masih bisa dibagi menjadi beberapa area yang punya fungsi masing-masing, seperti terlihat pada gambar di bawah ini.

Selain dibagi menjadi 4 lobus, cerebrum (otak besar) juga bisa dibagi menjadi dua belahan, yaitu belahan otak kanan dan belahan otak kiri. Kedua belahan itu terhubung oleh kabel-kabel saraf di bagian bawahnya. Secara umum, belahan otak kanan mengontrol sisi kiri tubuh, dan belahan otak kiri mengontrol sisi kanan tubuh. Otak kanan terlibat dalam kreativitas dan kemampuan artistik. Sedangkan otak kiri untuk logika dan berpikir rasional.

\section{Cerebellum (Otak Kecil)}

Otak Kecil atau Cerebellum terletak di bagian belakang kepala, dekat dengan ujung leher bagian atas. Cerebellum mengontrol banyak fungsi otomatis otak, diantaranya: mengatur sikap atau posisi tubuh, mengkontrol keseimbangan, koordinasi otot dan gerakan tubuh. Otak Kecil juga menyimpan dan melaksanakan serangkaian gerakan otomatis yang dipelajari seperti gerakan mengendarai mobil, gerakan tangan saat menulis, gerakan mengunci pintu dan sebagainya.
Jika terjadi cedera pada otak kecil, dapat mengakibatkan gangguan pada sikap dan koordinasi gerak otot. Gerakan menjadi tidak terkoordinasi, misalnya orang tersebut tidak mampu memasukkan makanan ke dalam mulutnya atau tidak mampu mengancingkan baju.

\section{Brainstem (Batang Otak)}

Batang otak (brainstem) berada di dalam tulang tengkorak atau rongga kepala bagian dasar dan memanjang sampai ke tulang punggung atau sumsum tulang belakang. Bagian otak ini mengatur fungsi dasar manusia termasuk pernapasan, denyut jantung, mengatur suhu tubuh, mengatur proses pencernaan, dan merupakan sumber insting dasar manusia yaitu fight or flight (lawan atau lari) saat datangnya bahaya.

Batang otak dijumpai juga pada hewan seperti kadal dan buaya. Oleh karena itu, batang otak sering juga disebut dengan otak reptil. Otak reptil mengatur "perasaan teritorial" sebagai insting primitif. Contohnya kita akan merasa tidak nyaman atau terancam ketika orang yang tidak dikenal terlalu dekat dengan kita. Batang Otak terdiri dari tiga bagian, yaitu:

Mesencephalon atau Otak Tengah (disebut juga Mid Brain) adalah bagian teratas dari batang otak yang menghubungkan Otak Besar dan Otak Kecil. Otak tengah berfungsi dalam hal mengontrol respon penglihatan, gerakan mata, pembesaran pupil mata, mengatur gerakan tubuh, dan pendengaran.

Medulla oblongata adalah titik awal saraf tulang belakang dari sebelah kiri badan menuju bagian kanan badan, begitu juga sebaliknya. Medulla mengontrol fungsi otomatis otak, seperti detak jantung, sirkulasi darah, pernafasan, dan pencernaan.

Pons merupakan stasiun pemancar yang mengirimkan data ke pusat otak bersama dengan formasi reticular. Pons yang menentukan apakah kita terjaga atau tertidur. 


\section{Limbic System (Sistem Limbik)}

Sistem limbik terletak di bagian tengah otak, membungkus batang otak ibarat kerah baju. Limbik berasal dari bahasa latin yang berarti kerah. Bagian otak ini sama dimiliki juga oleh hewan mamalia sehingga sering disebut dengan otak mamalia. Komponen limbik antara lain hipotalamus, thalamus, amigdala, hipocampus dan korteks limbik. Sistem limbik berfungsi menghasilkan perasaan, mengatur produksi hormon, memelihara homeostasis, rasa haus, rasa lapar, dorongan seks, pusat rasa senang, metabolisme dan juga memori jangka panjang.

Bagian terpenting dari Limbik Sistem adalah Hipotalamus yang salah satu fungsinya adalah bagian memutuskan mana yang perlu mendapat perhatian dan mana yang tidak. Misalnya lebih memperhatikan anak sendiri dibanding dengan anak orang yang tidak dikenal. Mengapa? Karena kita punya hubungan emosional yang kuat dengan anak sendiri. Begitu juga, ketika membenci seseorang, malah sering memperhatikan atau mengingatkan. Hal ini terjadi karena punya hubungan emosional dengan orang yang dibenci.

Sistem limbik menyimpan banyak informasi yang tak tersentuh oleh indera. Dialah yang lazim disebut sebagai otak emosi atau tempat bersemayamnya rasa cinta dan kejujuran. Carl Gustav Jung menyebutnya sebagai "Alam Bawah Sadar" atau ketidaksadaran kolektif, yang diwujudkan dalam perilaku baik seperti menolong orang dan perilaku tulus lainnya. LeDoux mengistilahkan sistem limbik ini sebagai tempat duduk bagi semua nafsu manusia, tempat bermuaranya cinta, penghargaan dan kejujuran.

\section{Perbedaan Fungsi Otak Kanan \& Otak Kiri}

Otak besar atau cerebrum yang merupakan bagian terbesar dari otak manusia adalah bagian yang memproses semua kegiatan intelektual, seperti kemampuan berpikir, menalarkan, mengingat, membayangkan, serta merencanakan masa depan.Perbedaan dua fungsi otak sebelah kiri dan kanan akan membentuk sifat, karakteristik dan kemampuan yang berbeda pada seseorang. Perbedaan teori fungsi otak kiri dan otak kanan ini telah populer sejak tahun 1960-an, dari hasil penelitian Roger Sperry.
Otak besar dibagi menjadi belahan kiri dan belahan kanan, atau yang lebih dikenal dengan Otak Kiri dan Otak Kanan. Setiap belahan mempunyai fungsi yang berbeda. Otak kiri berfungsi dalam hal-hal yang berhubungan dengan logika, rasio, kemampuan menulis dan membaca, serta merupakan pusat matematika. Beberapa pakar menyebutkan bahwa otak kiri merupakan pusat Intelligence Quotient (IQ).

Sementara itu otak kanan berfungsi dalam perkembangan Emotional Quotient (EQ). Misalnya sosialisasi, komunikasi, interaksi dengan manusia lain serta pengendalian emosi. Pada otak kanan ini pula terletak kemampuan intuitif, kemampuan merasakan, memadukan, dan ekspresi tubuh, seperti menyanyi, menari, melukis dan segala jenis kegiatan kreatif lainnya.

Perbedaan teori fungsi otak ini belum terjadi sampai dengan manusia mencapai usia kurang lebih 12 tahun. Setalah menjelang usia tersebut barulah terjadi yang dinamakan lateralisasi. Pada awal mulanya dinyatakan bahwa hemisfir kiri

Gambar 3. Perbedaan Fungsi Otak Kiri dan otak Kanan

ditugaskan untuk urusan bahasa dan kanan hal-

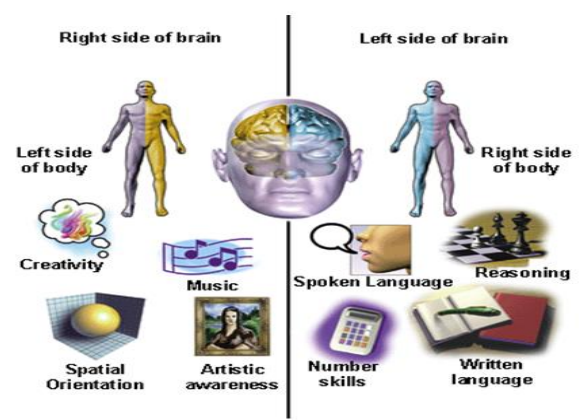

hal lain. perkembangan terakhir menunjukkan bahwa hemisfir kanan pun ikut bertanggung jawab akan penggunaan bahasa . (Dibahas lebih lanjut dalam otak dan bahasa)

Belahan otak mana yang lebih baik? Keduanya baik. Setiap belahan otak punya fungsi masingmasing yang penting bagi kelangsungan hidup manusia. Akan tetapi, menurut penelitian, sebagian besar orang di dunia hidup dengan lebih mengandalkan otak kirinya. Hal ini disebabkan oleh pendidikan formal (sekolah dan kuliah) lebih banyak mengasah kemampuan otak kiri dan hanya sedikit mengembangkan otak kanan. 
Orang yang dominan otak kirinya, pandai melakukan analisis dan proses pemikiran logis, tetapi kurang pandai dalam hubungan sosial. Mereka juga cenderung memiliki telinga kanan lebih tajam, kaki dan tangan kanannya juga lebih tajam daripada tangan dan kaki kirinya. Sedangkan orang yang dominan otak kanannya bisa jadi adalah orang yang pandai bergaul, tetapi mengalami kesulitan dalam belajar hal-hal yang teknis.

Ada banyak cara untuk mengetahui apakah seseorang dominan otak kanan atau dominan otak kiri. Misalnya dengan melihat perilaku seharihari, cara berpakaian, dengan mengisi kuisioner yang dirancang khusus atau dengan peralatan Electroencephalograph yang bisa mengamati bagian otak mana yang paling aktif.

\section{OTAK DAN BAHASA HUBUNGAN OTAK DAN BAHASA}

Untuk mengetahui bagaimanakah hubungan bahasa dengan otak melalui sudut pandang neurolinguistik, maka di bawah ini akan dibahas pengertian bahasa. Untuk pengertian otak dan strukturnya sudah dibahas sebelumnya.

Bahasa adalah alat verbal yang digunakan untuk berkomunikasi. Bahasa adalah suatu sistem simbol lisan yang arbitrer yang dipakai oleh anggota suatu masyarakat bahasa untuk berkomunikasi dan berinteraksi antar sesamanya, berlandaskan pada budaya yang mereka miliki bersama. Pendapat bahasa menurut Brown adalah seperangkat symbol (vokal maupun visual) yang sistematis, manasuka, mengonvensionalkan makna kata yang dirujuk, dan dipakai untuk berkomunikasi oleh manusia, dalam sebuah komunitas atau budaya wicara, dan dikuasai oleh semua orang dalam cara yang sama.

Dari beberapa pendapat di atas, dapat diartikan bahwa bahasa adalah suatu sistem lambang atau simbol yang sistematis yang digunakan oleh suatu komunitas bahasa dan dikuasai oleh semua orang dalam cara yang sama untuk berkomunikasi.

\section{HEMISFIR KIRI DAN HEMISFIR KANAN}

Setelah pengertian bahasa dan otak, selanjutnya akan dibahas mengenai hubungan otak dan bahasa. Otak terdiri dari dua belahan (hemisfer) yakni, hemisfer kiri dan kanan. Bagian manakah yang lebih berhubungan dengan bahasa? Ada pandangan yang menyatakan bahwa kebahasaan adalah tanggung jawab dari hemisfir kiri. Di bawah ini akan dipaparkan beberapa penelitian tentang hal tersebut.

Pandangan yang menyatakan bahwa kebahasaan tersebut tanggung jawab hemisfir kiri tidak sepenuhnya salah. Penelitian Wada (1949) yang memasukkan cairan ke kedua hemisfir menunjukkan bahwa bila hemisfir kiri yang "ditidurkan" maka terjadilah gangguan wicara. Tes yang dinamakan dichotic listening test yang dilakukan oleh Kimura (1961) juga menunjukkan hasil yang sama. Kimura memberikan input, katakanlah kata da pada telinga kiri, dan ba pada telinga kanan secara simultan. Hasil eksperimen ini menunjukkan bahwa input yang masuk lewat telinga kanan lebih akurat daripada yang lewat telinga kiri.

Salain itu, ada nama operasi yang dinamakan hemispherectomy. Operasi ini satu hemisfir diambil dalam rangka mencegah epilepsy. Terbukti juga bahwa bila hemisfir kiri yang diambil maka kemampuan berbahasa orang itu menurun drastis. Sebaliknya, bila yang diambil hemisfir kanan, orang tersebut masih dapat berbahasa, meskipun tidak sempurna.

Namun, selain dari penelitian tersebut di atas, ada penelitian yang menyatakan bahwa penelitian di atas tidak sepenuhnya benar. Seperti dikatakan sebelumnya, anak sebelum usia 12 tahun belum terjadi lateralisasi. Hal tersebut terbukti dengan adanya kasus anak di bawah usia belasan yang cedera. Anak yang cedera hemisfir kirinya dapat memperoleh bahasa seperti anak yang normal. Hal ini menunjukkan bahwa hemisfir kanan pun mampu untuk melakukan fungsi bahasa.

Ada beberapa ketidakmampuan manusia untuk berbahasa karena kerusakan organ otak. Ketidakmampuan berbahasa disebut patologi bahasa. Ada tiga masalah utama dalam patologi bahasa yang dibahas, yaitu disleksia, afasia, dan bahasa orang tuna rungu.

Menurut Mar'at hubungan antara otak dan bahasa dibahas terlebih dahulu berdasarkan kekidalan 
dan kekananan. Dikatakan bahwa pada oarng yang tidak kidal (kekananan) tingkah laku berbahasanya dikontrol oleh hemisfer otak sebelah kanan. Sedangkan pada orang kidal, tingah laku berbahasanya dikontrol oleh hemisfer otak sebelah kanan, meskipun sebenernya pada orang kidal kedua hemisfir sering ikut mengontrol.

Sistem penggunaan bahasa pada manusia terdiri dari beberapa subsistem, yaitu speech recognizer, sentence analyzer, sistem konseptual, generator kalimat, dan artikulator. Kelima subsistem ini mempunyai hubungan dengan kamus mental (lexicon).

Di dalam otak, semua subsistem berkaitan satu dengan yang lain dan merupakan satu kesatuan yang terintegrasi, yang disebut sistem penggunaan bahasa (language use system).

Gagasan otak kiri dan kanan membantu merumuskan rentetan pendekatan, metode, dan model pembelajaran yang beguna bagi pembelajaran bahasa. Berikut adalah peran neorolinguistik dalam pengajaran bahasa. Danesi (1988) misalnya menggunakan bimodalitas neorologis untuk menganalisis bagaimana berbagai metode pengajaran bahasa gagal yakni karena terlalu condong kepada proses otak kiri, metode-metode lama di kelas bahasa tak cukup merangsang proses otak kanan.

Krashenm Seliger, dan Harnett (1974) mendukung hipotesis bahawa para pembelajar bahasa kedua yang dominan otak kiri menyukai gaya deduktif, sementara yang dominan otak kanan terlihat lebih berhasil dalam lingkungan kelas yang induktif.

Cabang penelitian neurolinguistik yang berfokus pada peran belahan otak kanan dalam pemerolehan bahasa kedua. Obler mencatat bahwa dalam pembelajaran bahasa kedua, ada partisipasi penting belahan kanan dan partisipasi ini aktif dalam tahap-tahap awal pembelajaran bahasa kedua. Partisipasi ini didefinisikan sebagai strategi-strategi pemerolehan. Obler merujuk ini pada strategi penebakan makna dan penggunaan ujaran klise sebagai contoh-contoh aktvitas otak kanan.
Lahirnya NPL sebagai salah satu metode pembelajaran bahasa. NLP merupakan salah satu cara yang membuat seseorang mampu untuk memetakan semua proses yang terjadi dalam otaknya (didasarkan pada pengalamannya) dengan memprogram fungsi neuro-nya (otaknya) dengan menggunakan bahasa (linguistic) sehingga individu dapat mengubah aspek luar kehidupannya dengan cara mengubah sikap yang ada dalam pikiran mereka. Dari uraian tersebut dapat didefinisikan bahwa Neuro Linguistic Programming merupakan sebuah model yang memprogram interaksi antara pikiran dan bahasa (verbal dan nonverbal) sehingga dapat menghasilkan pikiran dan perilaku yang diharapkan. Dilts mengungkapkan tujulan NLP di antaranya adalah membantu manusia berkomunikasi lebih baik dengan diri mereka sendiri, mengurangi ketakutan tanpa alasan, mengontrol emosi negatif, stres, dan kecemasan.

Selain itu, NLP juga membantu manusia menciptakan tujuan positif bagi masa depannya, membantu memformulasikan tujuan khusus dan rencana yang akan membimbing mereka pada masa depan yang lebih baik. Bila digunakan dalam praktik pendidikan, NLP akan sangat bermanfaat untuk mengurangi kecemasan, rasa tidak percaya diri, serta tingginya indeks stres yang dimiliki peserta didik dalam mengikuti kegiatan belajar mengajar. Selain bagi peserta didik, NLP juga akan mampu membantu pengajar menumbuhkan rasa percaya dirinya sebagai seseorang yang harus menunjukkan citra baik dihadapan para peserta didik. Jika permasalahan yang dihadapi oleh pengajar dan peserta didik telah teratasi, besar kemungkinan keduanya akan merasakan kegiatan belajar mengajar yang menyenangkan dan efektif. Ghannoe mengungkapkan bahwa jenis metode NLP dibagai menjadi sembilan teknik, yaitu meta model, milton model, anchoring, metafora, reframing, sistem representasi, submodalitas, perseptual positions, dan metaprogram. Penerapan metode pemetaan pikiran yang merupakan memaduan kegiatan otak kiri dan otak kanan secara efektif dan bersinergi. Penerapan model pembelajaran Accelereted dengan menggunakan pendekatan SAVI (Somatis. Audiotori, Visual, dan intelektual) dalam pengajaran bahasa dengan mengaktifkan 
otak kanan dan kiri. Penerapan model pembelajaran suggestopedia yang memanfaatkan peran otak kiri dan kanan dalam meningkatkan kualitas pengajaran bahasa.

\section{PEMBAHASAN}

Peneliti membahas peran neurolinguistik dalam pengajaran bahasa dalam bidang pemerolehan bahasa. Dalam pembahasan berikut ini akan dikupas perkembangan bahasa pada anak yang kemudian mengarah pada paparan tentang pemerolehan bahasa pertama dan kedua pada anak sebelum pada akhirnya mengangkat tentang gangguan berbahasa.

\section{Perkembangan Bahasa pada Anak dan Ragamnya \\ Perkembangan bahasa merupakan salah satu mata rantai pertumbuhan anak selain perkembangan lain seperti perkembangan motorik kasar, perkembangan pemecahan masalah visuo motor yang merupakan gabungan fungsi penglihatan dan motorik halus, serta perkembangan sosial.}

Perkembangan bahasa sering menjadi tolok ukur tingkat intelejensi anak meskipun pada hakikatnya perkembangan seorang anak merupakan suatu kesatuan yang utuh dan saling melengkapi. Artinya seorang anak tidak dapat dikatakan cerdas jika dia hanya bisa memecahkan masalah visuo motor dan fasih berbahasa tanpa diimbangi kemampuan bersosialisasi.

Setiap anak yang normal pertumbuhan pikirannya akan belajar B1 atau bahasa ibu dalam tahun- tahun pertama dalam hidupnya, dan proses ini terjadi hingga kira-kira umur 5 tahun. Sesudah itu pada masa pubertas (sekitar 12-14 tahun) hingga menginjak dewasa (sekitar 18-20 tahun), anak itu akan tetap belajar B1. Sesudah pubertas ketrampilan bahasa anak tidak banyak kemajuannya, meskipun dalam beberapa hal, umpamanya dalam kosakata, ia belajar B1 terus menerus selama hidupnya. Pemerolehan B1 kita anggap bahasa yang utama bagi anak karena bahasa ini yang paling mantap pengetahuan dan penggunaannya.
Ketika seorang anak sedang memperoeh bahasa B1 nya, terjadi dua proses, yaitu proses kompetensi dan proses performasi. Kedua proses ini merupakan dua proses yang berlainan. Kompetensi adalah proses penguasaan tata bahasa yang berlangsung secara tidak disadari. Proses kompetensi ini menjadi syarat untuk terjadinya proses performasi yang menyangkut proses pemaham dan proses memproduksi ujaran. Proses pemahaman melibatkan kemampuan mempersepsi kalimat yang didengar. Sedangkan proses memproduksi ujaran menjadi kemapuan linguistik selanjutnya.

Fungsi berbahasa merupakan fungsi yang paling kompleks di antara seluruh faset perkembangan sebagaimana yang dijabarkan di atas. Indikator perkembangan bahasa ini meliputi fungsi reseptif yaitu kemampuan anak untuk mengenal dan bereaksi terhadap seseorang, terhadap kejadian lingkungan sekitarnya, mengerti maksud mimik dan suara dan akhirnya kata-kata dan fungsi ekspresif, yaitu Kemampuan anak mengutarakan keinginannya dan pekirannya. Fungsi ekspresif ini dipengaruhi fungsi reseptif dan merupakan kemampuan yang lebih kompleks mengingat anak memulai dengan komunikasi preverbal, dilanjutkan komunikasi dengan ekspresi wajah, gerakan tubuh, dan pada akhirnya dengan menggunakan kata-kata atau komunikasi verbal (Pusponegoro, 1997:80). Tabel berikut meringkas tahapan perkembangan bicara pada anak yang meliputi fungsi reseptif dan ekspresif dimulai sejak bayi baru lahir hingga berumur 4 tahun.

Dengan mengacu pada tabel perkembangan bicara di atas, maka anak dikatakan mengalami keterlambatan bicara atau kesulitan berbahasa jika kemampuannya menyimpangan dari standar tersebut. Keterlembatan bicara terjadi pada 3$15 \%$ anak, dan merupakan kelainan perkembangan yang paling sering terjadi. Dari jumlah tersebut, sebanyak $1 \%$ anak yang mengalami keterlambatan bicara tetap tidak dapat berbicara. 30\% dari anak dengan keterlambatan ringan akan sembuh atau menjadi normal dengan sendirinya. Sisanya, $70 \%$ akan mengalami kesulitan berbahasa, kurang pandai, atau mengalami kesulitan belajar lainnya. 
Penyebab keterlambatan bicara dan berbahasa secara umum sangat beragam, diantaranya: 1) retardasi mental yang menyebabkan kurangnya kepandaian anak dibandingkan anak lain seusianya, 2) gangguan pendengaran, 3) kelainan organ bicara, 4) mutisme selektif atau ketidakmauan berbicara pada keadaan tertentu, 5) deprivasi atau kurangnya stimuli dari lingkungan, 6) kekurangan gizi yang mengakibatkan kelainan saraf, dan 7) autisme atau deviansi komunikasi baik dalam berbahasa maupun bertingkah laku yang sedang tren dibicarakan saat ini (Sutardi, 1997:67).

Kajian tentang keterlambatan atau gangguan bicara di beberapa literatur psikologi bahasa masih terbatas pada kesulitan berbicara dalam tataran umum. Kesulitan berbicara yang megkerucut pada kemampuan berbahasa dari tinjauan sitaksis dan pragmatis belum banyak diangkat. Carrol (1986:30) menggolongkan gangguan bicara menjadi 4 (empat), yaitu: 1) gangguan bicara pada anak dengan keterlambatan mental, 2) gangguan bicara pada anak-anak penderita tunarungu, 3) gangguan bicara pada anak penyandang autisma, dan 4) gangguan bicara pada anak yang mengalami cidera otak.

\section{Pemerolehan Bahasa Pertama pada Masa Awal}

Pemerolehan bahasa pada anak yang baru lahir berawal dari suara tangisnya yang menjadi bentuk respon terhadap stimuli dari lingkungannya. Caranya merespon akan berkembang seiring kematangan mentalnya. Selanjutnya anak akan terus menyimpan stimuli bahasa pada memorinya. Pemerolehan bahasa pertama, atau yang kerap disebut bahasa ibu, merupakan proses kreatif dimana aturan-aturan bahasa dipelajari anak berdasarkan input yang diterimanya dari bentuk tersederhana hingga bentuk yang paling kompleks.

Anak akan lebih cepat menguasai bahasa jika ia memperoleh bahasa dalam masa emas atau periode ideal (critical age) yaitu usia 6-15 tahun. Pada teori lain diasumsikan bahwa usia kritis tersebut berkisar 0-6 tahun, namun pada intinya batasan periode ideal yang dimaksud adalah prapubertas. Menurut Lanneberg (dalam Subyakto, 1992) pada masa emas otak manusia masih sangat elastis sehingga memungkinkan seorang anak memperoleh bahasa pertama dengan mudah dan cepat. Adapun pada usia pubertas telah dicapai kematangan kognitif pada saat selesainya fungsi-fungsi otak tertentu, khususnya fungsi verbal yang menjadi mantap di bagian otak sebelah kiri. Hal inilah yang disebut lateralisasi. Masa kritislah yang bertanggung jawab atas lateralisasi yang membuat proses pemerolehan bahasa secara alamiah akan berkurang hingga akhirnya hilang sama sekali. Efektifnya pemerolehan bahasa pada usia tersebut telah diujikan dalam beberapa penelitian. Hipotesis bahwa periode usia di atas disebut masa emas pemerolehan bahasa diperkuat oleh beberapa kasus keterlambatan bicara pada orang dewasa yang memperoleh bahasa di atas usia 15 tahun. Sebut saja beberapa nama seperti Amila dan Kayla yang ditemukan di belantara India pada tahun 1920; Genie yang terisolir dari kehidupan manusia dan segala kontak sosial hingga tahun 1970; dan Victor yang ditemukan di hutan Aveyson pada tahun 1978. Nama yang terakhir ini kisah hidupnya difilmkan dimana diceritakan tentang betapa sulitnya mengembalikan anak pada kemampuan berbahasa dan berkomunikasi secara sosial dengan seutuhnya. Keterlambatan pemerolehan bahasa berakibat ketidakmampuan secara sepenuhnya penguasaan morfologis dan sintaktika bahasa (Field, 2003:73).

Contoh kasus keterlambatan pemerolehan bahasa terjadi pada Chelsea yang mulai memperoleh bahasa saat berusia 31 tahun. Bermula dari kecerobohan diagnosis dokter yang menyebutkan bahwa Chelsea mengalami keterlambatan mental, dia tidak pernah dilibatkan dalam kontak sosial yang memungkinkan pemerolehan bahasanya. Setelah beranjak dewasa baru diketahui bahwa Chelsea menderita tuli yang sebetulnya bisa diatasi dengan diajari bahasa isyarat. Setelah dipasang alat bantu dengar, ternyata Chelsea bisa berbicara dan menirukan ucapan orang lain. Waktu yang dibutuhkan Chelsea lebih lama dibandingkan waktu pemerolehan bahasa anak pada masa emas. Hasil penelitian lain menyebutkan bahwa anak yang diajarkan menggunakan bahasa isyarat pada usia 0-6 tahun lebih baik dalam pemahaman dan produksi kata daripada yang belajar pada usia 12 tahun ke atas. Kesimpulannya, di atas masa emas otak manusia 
tidak bisa secara maksimal memperoleh kemampuan sintaktik dan morfologis. Dus, adalah benar bahwa ada ungkapan mengajari (bahasa, membaca, mengaji, dll.) anak kecil adalah bagaikan menulis di atas batu dan mengajari orang tua bagaikan menulis di atas air.

Kemampuan menggunakan bahasa dalam proses pemerolehan bahasa secara sistimatis dan akurat memang tidak mudah. Pernyataan ini diperkuat oleh studi Bellugi dan Klima (dalam Fromkin, 1999) yang menunjukkan bahwa anak tunarungu yang tumbuh dan dibesarkan oleh orang tua tunarungu dapat menguasai bahasa isyarat. Kemampuan memproduksi kata anak tunarungu ternyata lebih cepat dibandingkan kemampuan memproduksi kata pada anak normal. Tidak mudahnya pemerolehan kemampuan ini membuktikan bahwa pengendalian otot larinks dan organ bicara pada anak normal lebih kompleks jika dibandingkan dengan pengendalian otot tangan pada anak tunarungu.

Pada kasus di atas tidak bisa diasumsikan bahwa bahasa isyarat lebih mudah dibandingkan bahasa lisan karena keduanya memiliki kesamaan dalam hal universalitas linguistik, sistim gramatika, memungkinkan terjadinya perkembangan dan perubahan kebahasaan, dan tidak terlepas dari adanya faktor kesilapan berbahasa.

\section{Pemerolehan Bahasa Kedua dan Kesulitannya}

Pemerolehan bahasa selain penguasaan bahasa ibu atau bahasa pertama disebut bahasa kedua, ketiga dan seterusnya. Dalam masyarakat Jawa misalnya, bahasa Indonesia disebut sebagai bahasa kedua jika anak dibesarkan dalam komunitas wicara bahasa Jawa.

Pemerolehan bahasa lebih baik jika diawali sejak dini. Mc Laughin dan Genesee, pakar psikolinguistik, berpendapat bahwa anak akan lebih cepat belajar bahasa tanpa kesukaran dibandingkan dengan orang dewasa. Selain itu Eric H. Lennenberg, seorang pakar neurolinguistik, juga menegaskan bahwa kondisi otak mendukung pendapat tersebut. Sebelum masa pubertas, otak atau daya pikir anak lebih lentur dan plastis sehingga dapat diajari bahasa apapun dengan lebih mudah. Daya penyerapan bahasa pada anak berfungsi secara otomatis, cukup dengan selfexposure atau dilibatkan dalam komunikasi partisipatif dalam bahasa target. Pasca pubertas kelenturan ini akan berkurang dan pencapaiannya tidak maksimal (Field, 2003:84).

Secara umum ada dua pendapat mengenai pemerolehan bahasa kedua. Pertama, anak sejak lahir sudah dibiasakan terekspos dengan berbagai bahasa. Kedua, anak belajar bahasa kedua setelah bahasa ibu dapat diucapkan dengan baik. Kedua pendapat ini sama baiknya, namun demikian tetap memiliki kekurangan. Metode pertama dapat berakibat munculnya keterlambatan berbicara karena otak anak bekerja keras memetakan bahasa apa yang digunakan oleh orang yang mengajaknya berbicara. Namun hal ini tidak berlangsung lama, saat anak makin besar kemampuan itu akan terasah dengan sendirinya. Metode kedua mengakibatkan pelafalan bahasa kedua akan lebih buruk daripada anak dengan metode pertama. Anak dalam metode pertama akan terbiasa dengan pengucapan dan aksen yang lebih jelas. Sungguhpun begitu, kedua metode ini dapat dipakai dengan catatan memperhatikan suasana pemerolehan bahasa yang bersifat interaktif, motivatif dan atraktif.

Kesulitan pada pemerolehan bahasa kedua masih terkait dengan teori masa emas seperti yang dijelaskan di atas. Secara umum kita melihat bahwa kemudahan anak belajar bahasa makin lama makin berkurang setelah umur 5-7 tahun, sampai menjadi agak sukar dan lambat setelah pubertas sehingga orang jarang mencapai kefasihan fonologi bahasa kedua jika ia mempelajarinya sesudah pubertas atau setelah berakhirnya masa emas. Namun demikian, menurut Schovel dan Krashen kemampuan belajar bahasa kedua tidak berkurang terlalu banyak meskipun proses laterlisasi telah usai (Subyakto-Nababan, 1992:66)

\section{Gangguan Berbahasa}

Dalam hal ini yang perlu diperhatikan adalah bahwa gangguan berbahasa berdampak pada 2 (dua) hal. Pertama, Lambat dalam pemerolehan bahasa - sebagai contoh, anak berusia lima tahun memiliki kompetensi bahasa setara dengan anak usia dua tahun. Kedua, Menyimpang dari bentuk baku pada anak yang memperoleh bahasa dengan urutan yang berbeda dari kebanyakan anak, atau 
anak tersebut memiliki kemampuan yang sangat berbeda dari penutur asli bahasanya sendiri.

Adapun jika ditinjau dari asalnya, gangguan berbahasa dapat dikategorikan kedalam 2 (dua) kelompok. Pertama, gangguan berbahasa yang berkembang, artinya gangguan akibat kelainan yang dibawa sejak lahir. Pada sebagian anak, terjadi kesulitan dalam pemerolehan bahasa akibat kelainan tumbuh kembang. Kedua, gangguan berbahasa yang diperoleh, artinya gangguan akibat operasi, stroke, kecelakaan atau penuaan.

Gangguan berbahasa dan berkomunikasi dapat diakibatkan faktor medis dan faktor lingkungan. Faktor medis berimplikasi pada gangguan berbicara, gangguan berbahasa dan gangguan berpikir. Contoh faktor medis yaitu gangguan sebagai akibat cidera otak yang menyebabkan kerusakan sistem syaraf, gangguan psikogenik, dan gangguan pada sistem mekanisme organ wicara. Demikian pula halnya dengan kerusakan sistem saraf yang menyebabkan terputusnya jaringan antara wilayah auditori dan produksi tutur sehingga pesan ujaran tidak tersampaikan.

Permasalahan berbicara sebagaimana yang dijelaskan di atas bersifat permanen yang menyebabkan ketidakmampuan berbahasa secara baik dan benar. Adapun beberapa gangguan lain bersifat temporer sehingga mengakibatkan kekurangmampuan berbahasa. Disebut kurang karena tidak mengacu pada kata "tidak" melainkan "belum". Misalnya pada penderita gagap yang disebabkan pengaruh perasaan afektif sehingga pikiran dan ucapan tidak bersambung dengan baik, kesukaran melafalkan kata-kata tertentu dan kurang menguasai topik pembicaraan (Gleason dan Ratner, 1998:75).

Kekurangmampuan berbahasa sebagaimana dijelaskan di atas pada hakikatnya dapat terjadi pada tiga tahapan rekonstruksi ingatan kebahasaan yang membangun proses pemerolehan bahasa secara lengkap. Tahapan pertama yaitu masukan. Pada saat seseorang mendengar atau membaca suatu wacana ia membuat catatan mengenai isi atau pesan kebahasaan sekaligus membuat interpretasi. Pada penderita gangguan neurologis tahap ini mempersulit proses interpretasi sehingga menghalangi keberlangsungan proses selanjutnya. Tahapan kedua yaitu penyimpanan. Para ahli membedakan dua konsep penyimpanan yaitu penyimpanan jangka pendek dan jangka panjang. Penyimpanan jangka pendek berupa kata-kata atau angka sejumlah maksimal 7 frase sehingga orang dapat mengingat 7 digit nomor telepon dalam jangka waktu pendek. Adapun penyimpanan jangka panjang menyangkut pesan kalimat yang dapat dipelihara untuk jangka waktu lama yang berbeda dari satu individu ke individu yang lain. Yang terakhir yaitu tahap hasil dimana terjadi kontras antara kedua jenis ingatan, artinya makin lama seorang pendengar mendapat kesempatan mengingat suatu ujaran, makin sedikit bentuk yang diingat, sebaliknya makin banyak makna yang diingat.

Baik ketidakmampuan maupun kekurangmampuan berbahasa yang diartikan sebagai gangguan bicara permanen dan temporer dapat dikategorikan ke dalam 3 (tiga) jenis. Pertama, gangguan dalam mengkondisikan ketidaksempurnaan organ. Kedua, gangguan berkognisi. Ketiga, gangguan mengolah informasi linguistik.

Contoh kategori pertama di atas yaitu yang dialami tunarungu, tunanetra dan penyandang gangguan mekanisme berbicara. Ketidaksempurnaan organ menyebabkan pendidikan tunarungu diprioritaskan pada pengajaran bahasa isyarat. Dengan menggunakan bahasa isyarat sebagai bahasa ibu, tunarungu kemudian memahami bahasa lisan dan tulis sebagai bahasa kedua. Dewasa ini mengajarkan pemahaman membaca gerak bibir lebih ditekankan. Namun demikian bagi penderita tunarungu dengan kerusakan pendengaran yang sangat parah hanya dapat diajari dengan bahasa isyarat.

Mengingat rumitnya fase belajar bahasa anak tunarungu yang bertingkat dari bahasa isyarat dan membaca gerak bibir, sebagai imbasnya dibutuhkan waktu yang lebih lama untuk belajar membaca dan menulis. Oleh karenanya kemampuan baca tulis anak tunarungu lebih lambat dibandingkan anak normal. Keterampilan komunikasi yang dicapai terbatas pada 
komunikasi tatap muka atau facetoface, dengan demikian tanpa teknologi visual sulit dilakukan percakapan pertelepon.

Secara umum perkembangan bahasa pada anak tunarungu ditentukan oleh 3 (tiga) faktor mendasar, yaitu: 1) tingkat kerusakan pendengaran, 2) status pendengaran orang tua (apakah normal atau tunarungu), dan 3) usia diperkenalkan pada sistem komunikasi tertentu serta konsistensi latihan berkomunikasi (Carrol, 1986:65).

Pada penderita tunanetra beberapa keraguan mengenai kemampuannya berbahasa kerap dilontarkan. Salah satu pertanyaan yang sering muncul yaitu apakah kelainan visual mengakibatkan keterlambatan dalam memperoleh bahasa? Hal ini mengingat kondisi anak yang tidak terbantu dengan ekspresi wajah, bahasa tubuh atau pandangan pada obyek disekitarnya. Riset membuktikan bahwa anak tunanetra ternyata memperoleh sistem fonologi lebih lambat daripada anak normal. Anak tunanetra kadang-kadang bingung dengan fonem yang mirip dalam pengucapan, misalnya $/ \mathrm{n} / \mathrm{dan}$ $/ \mathrm{m} /$. Kemampuan anak tunanetra sama dengan anak normal ketika mulai meracau dan mengatakan kata-kata pertama. Namun demikian terdapat perbedaan pada isi kosakata awal mereka. Anak tunanetra umumnya kurang memvariasikan kata kerja, hal ini menunjukkan bahwa mereka memiliki keterbatasan pengkategorian yang berdampak pada keberagaman kosakatanya.

Ketidaksempurnaan organ wicara menghambat kemampuan seseorang memproduksi ucapan (perkataan) yang sejatinya terpadu dari pita suara, lidah, otot-otot yang membentuk rongga mulut serta kerongkongan, dan paru-paru. Hal ini disebut gangguan mekanisme berbicara. Menurut Chaer (2002) berdasarkan mekanismenya, gangguan berbicara dapat terjadi akibat kelainan pada paru-paru (pulmonal), pada pita suara (laringal), pada lidah (lingual), serta pada rongga mulut dan kerongkongan (resonental).

Pada kategori kedua, gangguan berbahasa terjadi karena adanya gangguan berkognisi. Hal ini terjadi pada orang yang pikun (demensia), penderita sisofrenia dan depresif. Pada penderita demensia, gangguan berpikir menyebabkan ekspresi verbalnya diwarnai dengan kesukaran menemukan kata-kata yang tepat. Kalimat seringkali diulang-ulang, pembicaraan sering terputus karena arah pembicaraan tidak teringat atau sering berpindah ke topik lain. Artikel ini menitikberatkan pada kekurangmampuan berbahasa pada anak, sehingga gangguan akibat demensia tidak dibahas secara detail.

Sisofrenik dan depresif mengalami hambatan dalam melakukan curah verbal yang sesuai dengan konteks akibat gangguan berpikir. Curah verbal deprefis umpamanya, dicoraki topik yang menyedihkan, menyalahi dan mengutuk diri sendiri, kehilangan semangat bekerja dan gairah hidup, tidak mampu menikmati kehidupan, malah cenderung berupaya mengakhirinya.

Contoh yang disebutkan di atas jarang ditemui pada anak-anak. Gangguan berbahasa karena kognisi yang lebih umum ditemui yaitu pada penderita Down Syndrome dan Autisma. Pada penderita Down Syndrome kemampuan intelektualnya sangat beragam dan salah jika kita menganggap kemampuan berbahasa semua penderitanya sama. Menurut Kendler (Carrol, 1986:95) tingkatannya terbagi atas: ringan (IQ 53-68), sedang (IQ 36-52), berat (IQ 20-35) dan parah (IQ di bawah 20). Dengan demikian kemampuan linguistiknya mengacu pada kelainan kognitif yang dialaminya.

Kajian tentang Down Syndrome atau keterbelakangan mental menunjukkan adanya hubungan antara kelainan kognitif dengan kegagalan memperoleh kompetensi linguistik sepenuhnya. Secara umum perkembangan fonologisnya lambat. Hanya sedikit kosakata dapat dikuasai dan ucapannya cenderung pendek dan telegrafis (tanpa imbuhan dan kata sambung, mirip bahasa dalam telegram). Anak sindrom down juga bermasalah dengan pelafalan. Dengan suaranya yang khas parau, intonasinya tergolong abnormal.Komunikasi dengan menggunakan bahasa tubuh (gesture) lebih dipilih oleh anak dengan sindroma down berat dan parah. Adapun kemampuan sintaksisnya dapat dicapai pada usia dewasa, meskipun mereka lebih dapat menangkap kontruksi kalimat afirmatif daripada negasi. 
Secara umum dapat disimpulkan bahwa gangguan berbahasa, yang dialami penderita sindroma down baik anak-anak maupun dewasa, hanya bersifat terlambat (bukan bersifat kurang atau tidak mampu). Artinya dengan perkembangan yang berlangsung lamban, proses pemerolehan bahasa yang dilaluinya mirip dengan urutan normal meskipun pada sebagian penderita tidak dapat mencapai kompetensi penuh sebagai mana pembicara dewasa normal. Hal ini tergantung tingkat parahnya kelainan yang diderita.

Pada kasus Autisma terjadi kombinasi antara kelainan kognitif dan sosial. Penyandang autisma bisa jadi membisu hingga usia lima tahun, atau hanya membeo kata-kata orang dewasa yang didengarnmya. Hal ini mengindikasikan bahwa penyandang autisma memiliki keterbatasan alam pikir, artinya mereka tidak mampu memahami dunia dari sudut pandang orang lain. Segala aspek komunikasi sulit dicapai penyandang autisma, kecuali aspek fonologis yang pada sebagian penyandang tetap dapat dikuasai. Perkembangan ketrampilan bahasanya tidak saja mengalami keterlambatan tetapi juga penyimpangan.

Secara fonologis, artikulasinya cukup jelas meskipun sering muncul beragam kesalahan dalam penyebutan obyek. Misalnya substitusi atau menyebut dengan kata lain, menghilangkan suku kata tertentu, asimilasi dengan kata lain, menambahkan dengan suku kata yang salah. Intonasinya cenderung datar dan salah dalam membuat penekanan ucapan. Kemampuan sintaksisnya sangat lamban karena sering muncul kalimat peniruan atau echolalia, yaitu mengulang-ulang kalimat yang tidak relevan dengan konteks. Kemampuan memahami semantik juga lamban, misalnya membedakan antara "The girl feeds the baby" dengan "The baby feeds the girl".

Pada kategori ketiga, anak dapat mengalami gangguan berbahasa secara linguistik yaitu ketidakmampuan dalam pemerolehan dan pemrosesan informasi linguistik. Misalnya masalah kefasihan yang terjadi pada anak yang gagap dan latah atau pada penderita gangguan fisiologis yang menyangkut kesalahan formasi dan pengolahan organ artikulasi (seperti mulut, lidah, langit-langit, pangkal tenggorok dll.). Selain itu anak dapat menghadapi masalah baca tulis. Disini perlu dibedakan antara disleksia dan disgrafia. Disleksia atau kesulitan membaca kerap diikuti dengan disgrafia atau kesulitan menulis. Tingkat kelainan dan gejalanya bervariasi antar individu. Sebagian penderita disleksia juga mengalami keterbatasan fonologis misalnya tidak bisa menduga bagaimana membedakan ejaan kata atau bukan kata. Penderita lain sekedar menghafal ejaan kata dan tidak dapat mengingat ejaan kata-kata lain. Secara umum penderita disleksia mengalami kesulitan pada area kognitif tertentu, termasuk membedakan kiri/kanan, barat/timur; juga konsep waktu seperti hari, tanggal, bulan, tahun; serta pengolahan secara matematis.

\section{KESIMPULAN}

Dari paparan di atas dapat disimpulkan bahwa kemampuan berkomunikasi ditunjang dari proses pemerolehan kecakapan berbahasa. Kompleksitas bahasa menuntut akumulasi pemerolehan yang juga berkesinambungan dari tataran tersederhana hingga yang membutuhkan gabungan kemampuan berbahasa dan bersosialisasi. Mata rantai pertumbuhan kemampuan berbahasa tidak seragam pada satu orang dengan orang lainnya. Variasi inilah yang menghasilkan perbedaan pencapaian kemahiran kognitif yang difasilitasi kompetensi dan performasi berbahasa. Mutlaknya kebutuhan akan kemampuan berbahasa membuat tidak tepatnya sebutan ketidakmampuan berbahasa -melainkan menyebutnya sebagai kekurangmampuan berbahasa. Kekurangmampuan ini hanya bersifat gangguan atau keterlambatan berbahasa yang melampaui masa emas pemerolehan bahasa.

\section{DAFTAR PUSTAKA}

[1] Abdul Chaer, Abdul. Psikolinguistik Kajian Teoretik. Jakarta: Rineka Cipta. 2009.

[2] Brown, H. Douglas. Prinsip Pembelajaran dan Pengajaran Bahasa. Jakarta: Pearson Education. 2008. 
[3] Carrol, David W. 1986. Psychology of Language. Pacific Grove-California: Brooks/Cole Publishing Company.

[4] Dardjowidjojo, Soejono. Echa: Kisah Pemerolehan Bahasa Anak Indonesia. Jakarta: PT Grasindo. 2000.

[5] Dardjowidjojo, Soejono. Psikolinguistik: Pengantar Pemahaman Bahasa Manusia. Jakarta: Yayasan Obor Indonesia. 2010.

[6] Eric Jensen, Brain-Based Learning: Cara Baru dalam Pengajaran dan Pelatihan, Yogyakarta: Pustaka Pelajar, 2008

[7] Field, John. 2003. Psycholinguistics: a resource book for students. New York: Routledge.

[8] Fromkin, Victoria; Blair, David and Collins, Peter. 1999. An Introduction to Language. Sydney: Harcourt, Ltd

[9] Gleason, Jean Berko dan Ratner, Nan Bernstein. 1998. Psycholinguistics. Victoria: Wadsworth Thomson Learning.
[10] Ghannoe. Buku pintar NLP. Yogyakarta: Flash Books. 2010.

[11] Hernowo. Quantum reading. Jakarta: MLC. 2003.

[12] Mar'at, Samsunuwiyati. 2005. Psikolinguistik Suatu Pengantar. Bandung: Refika Aditama,2005.

[13] Pusponegoro, H.D. 1997. Apakah Perkembangan Anak Anda Normal? Dalam Simposium Autisme: Gangguan Perkembangan Pada Anak. Jakarta: Yayasan Autisme Indonesia.

[14] Sutardi, Rudi. 1997. Autisme: Gangguan Perkembangan pada Anak. Dalam Simposium Autisme: Gangguan Perkembangan Pada Anak. Jakarta: Yayasan Autisme Indonesia.

[15] Subyakto-Nababan, Sri Utari. 1992. Psikolinguistik: Suatu Pengantar. Jakarta: Gramedia Pustaka Utama 